Ssciendo Studia Anglica Posnaniensia 56s1 (2021): 411-424

doi: 10.2478/stap-2021-0005

\title{
THE GRAMMATICALIZATION OF THE EPISTEMIC ADVERB PERHAPS IN LATE MIDDLE AND EARLY MODERN ENGLISH
}

\author{
RAFAŁ MOLENCKI ${ }^{1}$
}

\begin{abstract}
Old and Early Middle English did not yet have modal sentential adverbs of low probability. Old Norse did not have such words, either. From the 13th century onwards first epistemic prepositional phrases of Anglo-Norman origin functioning as modal adverbials consisting of the preposition per/par and nouns such as adventure, case, chance were borrowed into Middle English. In the late 15th century an analogous hybrid form per-hap (s), the combination of the Old French preposition per/par 'by, through' and the Old Norse noun hap(p) 'chance', both singular and plural, was coined according to the same pattern and was gradually grammaticalized as a univerbated modal sentence adverb in Early Modern English. The Norse root happ- was the source of some other new (Late) Middle English words which had no cognate equivalents in the source language: the adjective happy with its derivatives happily, happiness, etc. and the verb happen.

Together with another new Late Middle English formation may-be, a calque of French peutêtre, perhaps superseded the competing forms mayhap, (modal) happily, percase, peradventure, perchance, prepositional phrases with the noun hap and, finally, per-hap itself in Early Modern English after two centuries of lexical layering or multiple synonymy. The history of perhaps is a clear example of grammaticalization, whereby a prepositional phrase became a modal adverb now also used as a discourse marker. We find here all the typical features of the process: phonetic attrition, decategorization, univerbation, and obligatorification.
\end{abstract}

Keywords: Grammaticalization; univerbation; lexical layering; modal adverb; low probability.

\section{Introduction}

In the article we will trace the rise and development of the epistemic sentential adverbs based on the root happ- in Late Middle and Early Modern English. The root was borrowed from Old Norse, which had the noun happ 'good luck, good fortune, chance' and it developed new derivatives and senses in English,

$1 \quad$ University of Silesia in Katowice. molencki@poczta.onet.pl 
found in the following words: the noun hap, the adjective happy and the adverb happily, the verb happen and the adverb perhaps, which all arose in Late Middle English. Their diffusion was rapid in subsequent centuries in all dialects and registers as evidenced by the Corpus of Middle English Prose and Verse $(C M E P V)$. Despite the fact that the noun hap itself became obsolescent in Early Modern English, its derivatives are now high frequency words. They had eliminated most of their earlier Medieval English synonyms in line with the idea of layering (cf. Hopper 1991; Vanhowe 2008; Martín Arista 2011, 2014; Brems 2012; Allan 2016), a concept developed predominantly for syntactic processes within grammaticalization: "within a broad functional domain, new layers are continually emerging. As this happens, the older layers are not necessarily discarded, but may remain to coexist with and interact with the newer layers" (Hopper 1991: 22). However, I believe that the concept can also be extended to cases of multiple lexical synonymy.

The modal adverb perhaps is a good example of grammaticalization, where the original prepositional phrase went down the cline to become a univerbated sentence adverb. In Modern English it also became a discourse marker similarly to, for example, indeed, derived from the prepositional phrase in deed (Traugott 1995; Suzuki 2018a). Thus this article provides the expansion of the empirical base of the phenomenon of grammaticalization. Suzuki (2018a) has already discussed the grammaticalization and (inter)subjectification of perhaps, but his study does not take into account the other synonymous modal adverbials based on the root happand is limited to Early Modern English and later up to modern times, leaving aside pertinent Late Middle English instances of -hap- adverbials listed, for example, in the Middle English Dictionary and discussed in detail in this article.

In cross-linguistic perspective one can observe that the major sources of adverbs of probability are (cf. Ramat \& Ricca 1998: 232):

- verbs of low or weak modality + copula/linking verb: English maybe, mayhap, French peut-être, Romanian poate, Swedish kan-ske, Dutch misschien, Polish (być) może, Lithuanian galbūt

- $\quad$ equivalents of easily: Old English eaðe(lice), German vielleicht (from MHG vil lìchte 'much easy'), Old Polish snadź, snadnie, Czech and Slovak snad

- nouns expressing chance, fate, luck, often in prepositional phrases: Latin forte, forsitan, Old French parauntre, English perhaps, perchance

- $\quad$ verbs of thinking, expecting, hoping: Old English wenunga 'with hoping', Polish przypuszczalnie 'supposedly'

- $\quad$ non-assertive forms of the verb 'know': Spanish quizá(s) from Old Spanish qui sabe 'who knows', Polish kto wie 'who knows', Albanian kushedi 'who it knows', Breton moarvad 'I know well', German and Old English ungewiss 'unknowingly, uncertainly' 
The items derived from these sources are represented in English throughout its history.

The illustrative language material for the study comes from the standard historical lexical databases (DOE, MED, DSL and $O E D$ ), the $C M E P V$ and William Shakespeare's plays. The short titles and dating of the examples cited in this article follow the practices of the compilers of these sources.

\section{Modal sentential adverbs in Old English}

Modal adverbs are mostly characteristic of spoken language, of which we have rather little evidence in medieval texts. This may explain relative paucity of such forms in the Old English corpus. The only common adverbs here are truth intensifiers such as witodlice, soplice, which expressed certainty and/or confirmation. At this stage of English we do not yet find many instances of (low) probability adverbs (cf. Goossens 1982; Swan 1988a, 1988b, 1991, 1996; Palander-Colin 1999; Traugott 2006). González Álvarez (1996: 222) claims that probability in Old English was "hardly ever expressed adverbially". Likewise Brinton (2017: 153) says that "Old English does not have pure probability evaluators". Fischer (2015: 55) observes that "epistemic modality in Old English could only be expressed via biclausal structures like" (3) below.

If there were adverbs used in such function, they were usually combined with modal verbs eaðe/eaðelice (moeg)/ '(it) may easily be the case' (cf. Nykiel 2010), as in (1) and (2) below. This phrase is found in the Old English glosses of Latin modal adverbs containing the root fors 'chance, fate' such as forte (the ablative of fors), fortasse, forsit, forsan and fortisan, grammaticalized and univerbated from the phrase fors 'chance' + sit, subjunctive of 'be' + the interrogative particle an 'whether' (clausal univerbation found also in, for example, all be it > albeit, cf. Molencki 1997). Another word or phrase glossing the Latin equivalents was weald, a word of uncertain etymology in Old English, combined with obligatory peah (cf. $B \& T$, s.v. weald), as in (5), still found as wald on its own in Early Middle English (6). Also forms based on the root wen-, i.e., gewene, the instrumental of the noun gewen 'hope', and wenunga, the gerundival form of the verb wenan 'to think, expect, hope', as in (7) and (8). Indeed, wenunga is the equivalent of Latin forsan, forsitan, fortassis and fortasse listed by Ælfric, a native speaker of Old English in his Grammar (7). Particularly interesting are northern Gospels glosses, where we find double variants, e.g., eaða $\nmid$ woenunga in (4) and (8).

(1) Bede 3 11.192.5: eaðe mæg, pæt me Drihten purh his geearnung miltsigan wille (cf. BEDA. Hist.eccl. 3.13, 254 si forte mihi Dominus per eius meritum misereri uoluerit). 'It may easily be (the case) that the Lord will have mercy on me for his merits'. 
(2) JnGl (Li) 8.19: si me sciretis forsitan et patrem meum sciretis gif gie uiston eaðe mæg æc faeder min gie uiston ( $\mathrm{Ru}$ ceðe moeg, $\mathrm{CpH}$ wen is). 'If you knew me, perhaps you would also know my father'.

(3) ApT 21.10 Eaðe mæg gewurðan pæet pu wite pæt ic nat. 'It may easily be the case that you know what I don't know'. (cf. Fischer 2015: 520)

(4) MkGl (Li) 11.13: cumque uidisset a longe ficum habentem folia uenit si quid forte inueniret in ea \& miððy gesæh fearra pæt ficbeam hæbbende leafo cuom gif huæt eaða 1 woenunga gemitte in ðær $\nmid$ on ðæm. (double glosses; Rushworth: eaða; West Saxon Gospels has soðlice) King James: 'and seeing a fig tree afar off having leaves, he came, if haply ['possibly'] he might find any thing thereon'.

(5) ÆCHom II, 2 194.132: Nyte ge ða micclan deopnysse godes gerynu. weald peah him beo alyfed gyt behreowsung. 'You do not know the great depths of God's mystery, perhaps repentance will be granted to him' [a1150(OE) Vsp.D.Hom.(Vsp D.14)112/22: Wealte peh him beo get alefd bereowsung].

(6) c1175 Orm. (Jun 1) 11815: Here icc unnderrstanndenn ma33...Patt I me sellf all ah itt wald batt deofell maz3 me scrennkenn. 'I can understand here...that I myself consider entirely possible that the devil may deceive me'.

(7) Ælfric's Grammar 228.16-229.1: Sume syndon DVBITATIVA, pæt synd twynigendlice. forsan wenunge. forsitan wenunge, fortassis and fortasse wenunge. ðas and ðyllice getacniað twynunge, hwæðer hit gewurðe oððe ne gewurðe. 'Some are DUBITATIVA which are dubitative forsan wenunge. forsitan wenunge, fortassis and fortasse wenunge. Those and the like express doubt, whether it happened or did not happen'.

(8) Mk 14.2: dicebant enim non in die festo ne forte tumultus fieret populi MkGl (Li) 14.2: cwedun forðon ne on dæge halgum ne pæt gewoene pæt mæge styrnisse giworða in ðæm folce. MkGl (Ru) 14.2: cuoedon forðon ne on dæge haligum $t$ bærlice ne pæt woenunge $\boldsymbol{t}$ eaðe maege styrenise geworðe ðæm folce. 'They said, "Not during the festival, for fear that there may be a riot among the people"'. (on multiple glosses see Fernández Cuesta \& Ponz Sanz 2016)

\section{Middle English low probability adverbs of Norman French origin}

No new modal sentential adverbs appear to have developed in Early Middle English. There cannot have been here any Scandinavian influence, as Old Norse does not adverbialize its sentence modifiers to the extent Old English does, cf. Swan (1996). Old Icelandic did not yet have such adverbs, either, but Modern 
Icelandic has kannski attributed to the influence of Norwegian kanskje. The other Scandinavian cognates are Faroese kanska and Swedish kanske. Beijering (2012: 139) wonders whether they are "loan translation or part of cross-linguistically regular grammaticalization path", as these modal adverbs were originally complex verb phrases consisting of modal kan, må, tör 'can, may' and main verbs such as ske, hända 'happen, occur'. There were alternations with synonyms of both the modal and the main verb, e.g., in Danish the form is måske and Middle and Early Modern Swedish also used kanhända, måhända, törhända. Similar forms are also found in closer medieval cognates of English, e.g., Middle Low German mach schên and the Middle Dutch phrase (het) mach schien 'it may happen', which was grammaticalized into the modern epistemic adverb misschien through clausal univerbation.

Anglo-Norman and Old French also used the phrase puet cel/il estre 'may it be' turned into the adverbial peut-être, which became a ready pattern for the English calque may-be first attested in the late 14th century and its coeval synonyms may-hap, may-fall formed according to the same strategies as in its sister Germanic languages discussed above, e.g.:

(9) a1150 Psautier d'Oxford 54.13: Put cel estre teniebres decalcherunt mei. (Latin: Forsitan tenebrae conculcabunt me.) 'Perhaps darknesses shall cover me'.

(10) a1400 Cursor Trin-C 17553: May be sum goost awey him ledde 'Maybe some ghost led him away'. (The same form in Fairfax MS, but Göttingen MS and the earliest Cotton Vespasian have: Mai fall sum gast awai him led - cf. (29) below).

Then, owing to the increasing number of argumentative texts written in (Late) Middle English, the language needed new adverbs of low probability and a useful source of them became Anglo-Norman French, the major lexifier for English at the time. French had developed new modal adverbials which were grammaticalized from prepositional phrases consisting of prepositions par/per/pour and nouns expressing something happening by chance: aventure, chaunce and cas (cf. the respective entries in $A N D$ and $M E D$ ). These phrases were first adopted by bilingual Anglo-French speakers and writers, as a result of which we find new Middle English adverbs per/par-adventure (sometimes syncopated to peraunter), per/par-case, per/par-chance (cf. Suzuki 2018a), e.g.:

(11) 1352 Borough of Leicester Customs i 131: si il eyent peraventure une beste ou deus si les fount clore denz mesoun de south lok issint qe les baylifs ne poient avenir. 'if they happen to have [by chance, perhaps have] 
an animal or two, they arrange to shut them up in the house under lock so that the bailiffs cannot come'.

(12) 1330 Assump. Virg. (B.M. MS.) 9: Par auenture ze haue nozt iherde How oure ladi went out of pis werde. 'Perhaps you haven't heard how Our Lady went out of this world'.

(13) (c1395) Chaucer CT.Mch. (Manly-Rickert) E.1670: Dispeire yow noght, but haue in youre memorie, Paraunter [vr. perauntir] she may be youre purgatorie. 'Do not despair, but have it in your memory, perhaps she may be your purgatory'.

(14) c1325 YBB Ed II xx 75: l'essonur ne purra mye par chaunce aver conisaunce 'perhaps the essoiner might possibly not know'.

(15) 1340 Hampole Pr. Consc. 2489: For our gude dedys er ofte done wrang, Or parchaunce done oute of charité. 'For our good deeds are often done wrong, or perhaps done out of charity'.

(16) 1346 YBB 20 i Ed III 149: Quant nous lavoms fait, et vous par cas le lessetz vers le clerke pur ceo qe ne voletz paier soun fee, qi defaut est cella? 'When we have executed the statute, and you possibly leave it in the Clerk's possession because you are unwilling to pay his fee, whose fault is that?'

(17) 1475 Paston Letters 1.482: To morow I purpose to ryde in-to Flaundrys..and, parcase, I shall see the assege at Nwse, ere I come ageyn iff I have tyme. 'Tomorrow I intend to ride to Flanders and perhaps I shall see the siege of Nuse before I come again if I have time'.

\section{The rise and grammaticalization of perhaps}

Thus from the 13th century onwards adverbialized phrases of probability of Anglo-Norman origin are borrowed into English, viz. per/paradventure/case/chance. All these new words developed two major senses: 'by chance' and 'maybe, possibly'. More or less at the same time Middle English borrowed the Norse word hap, which became a synonym of chance. In the late 15th century a novel Romance-Norse hybrid form consisting of an Anglo-French preposition combined with a Norse noun, both singular and plural, viz. per-hap and per-haps, was coined by analogy with the pure Romance formations and likewise came to be gradually grammaticalized as a univerbated adverb.

As written above in the introduction, the Norse root happ- was very productive in Middle English, yielding new English words which did not have cognate items in the source language: the noun hap, the adjective happy (Molencki in press), the verb happ(en)en (Molencki forthc.) and the adverb perhap(s). The first instances of the adverb are attested in the mid-15th century John Lydgate's minor poem A philosophre. According to the $O E D$ (s.v. perhaps) the first examples of 
c1430 are uncertain: "The reading of the MS. (Harl. 372 1f. 45, 51) may be per happous, but it may just as well be per happons, or, in the second instance, per happans. In this uncertainty the quots. are left here, as being the earliest traces of any form of the word." The $M E D$ dates these for c1475, i.e., half a century later:

(18) c1475 A philosophre (Hrl 372) p.34: She wol perhappous [?read: perhappons] maken hir avowe, That she wol take the mantle and the ryng. 'Perhaps she will make a vow that she will take the mantle and the ring'.

(19) c1475 A philosophre (Hrl 372) p.35: Par case thi men in mynde she kepethe hem alle, Perhappous [?read: Perhappans] one is loved that wol not fade. 'She possibly keeps all your men in mind, perhaps that one is loved who will not fade'.

The form par/per-hap is first found in the c1450 manuscript of Origo Mundi in a translation of a Welsh sentence and the $M E D$ compilers suggest that the text itself is almost a century older (examples (20) and (21)). The first clear instances of perhaps, which finally supplanted perhap, are found in the 16th century:

(20) ?a1450(?1350-75) Origo Mundi in Norris Anc.Corn.Drama (Bod 791)1352: Pan clewfyf vy an tan tyn, parhap y wrussen fye. 'perhaps I might flee'.

(21) (a1464) Capgr.Chron. (Cmb Gg.4.12) 85: Othir men write that on Johannes Patricius schul a mad this Cherch in tyme of Liberi the Pope; Perhap [vr. Up hap] this Pope mored it, or arayed it, as he ded many othir. 'Others write that John Patricius should have made this Church in the days of Pope Liberius; perhaps this pope improved it or put in order, as he did with many other things'.

(22) 1528 Roy Rede me (Arb.) 98: Savynge wother whyles perhapis They gett a feawe broken scrapis. 'Saving the other while perhaps they get a few broken scraps'.

(23) 1546 Supplic. of Poore Commons (E.E.T.S.) 85: Perhappes some one of vs hath hylded c. shepe. 'Perhaps one of us kept a hundred sheep'.

(24) 1590 Shakespeare Com. Err. ii.i.4: Perhaps some Merchant hath inuited him.

Before freezing or obligatorification (cf. Lehmann 1995; Haspelmath 2004) of the modal adverb per-hap (s) occurred in the 16th century, other prepositions had also been possible in the adverbial phrase, especially in and up(on), as can be seen in examples (25-28) below. Particularly interesting is the quotation from Wycliffe's Bible (25), where the earlier version has Romance perauenture while the later one has Germanic in hap for the Latin forsitan: 
(25) a1425(c1395) WBible(2) (Roy 1.C.8) Gen.20.11: In hap the drede of God is not in this place. [WB(1): perauenture pe drede of God is not in pis place; Latin: Forsitan non est timor Dei in loco isto.] 'Perhaps there is no fear of God in this place'.

(26) a1450(1412) Hoccl.RP (Hrl 4866) 411: But pogh I olde \& hore be, sone myin..Mi redde, in hap, zit the perfet may. 'My son, though I am old and hoary, yet perhaps my advice may be perfect'.

(27) a1450(c1410) Lovel.Grail (Corp-C 80)51.361: Wilen ze..In this vessel forth gone, and vppon hap neuere Comen Ageyn? 'Will you go forth in this vessel and perhaps never come again?'

(28) c1450(?a1400) Wars Alex.(Ashm 44) 4936: Pou sall here, apon happis, or pou hethen founde, Pat neuire hathill vndire heuen herd bot pi-selfe. 'Perhaps you shall hear before you find a heathen that no warrior under heaven ever heard about you'.

Suzuki (2018a) provides a detailed study of the occurrence, rivalry, and syntactic properties of peradventure, percase, perchance, and perhaps in Early Modern English and later up to modern times, which is based on the data extracted from the OED, A Corpus of English Dialogues (1560-1760) and the Brown family of corpora of contemporary English. His corpus survey and quantitative analyses clearly show that "peradventure, percase and perchance have undergone a steady decline through the sixteenth and the seventeenth centuries [...], whereas perhaps, the latest arrival has experienced a dramatic rise and eventually ousted the other adverbs in the seventeenth century" (2018a: 44). He also pays some attention to the pragmatic development of perhaps as a discourse marker in modern times (cf. also Heine 2013), which corroborates Traugott's (1989) idea of subjectification whereby linguistic expressions acquire new meanings which aim to convey the speaker's attitude. On the other hand, Busse's (2010, 2012: 294) analyses of Shakespeare's language demonstrate that perchance and perhaps still competed as "attitudinal stance adverbials" in what she calls Early Modern "Spoken English": in the comedies the ratio is 20 instances of perhaps vs. 19 of perchance and in the tragedies 12 vs. 13 , respectively.

Another Early Modern English synonym was the phrase may hap (or mayhaps) 'it may happen', first recorded in writing in the 16th century according to the $O E D$ and formed by analogy with such modal phrases as may be and may fall (cf. (10) above). The first univerbated instances are attested in the 18th century:

(29) 1533 John Heywood The Play of the Wether 815: May happe I wyll thynke on you when you be gone.

(30) 1719 Chit-Chat: But mayhap I may fit 'em as well. 
However, what we have here is the original verb phrase consisting of the modal may and the verb happ(en), obviously derived from the same Old Norse root. The formation is analogous with may-be and likewise it was univerbated, grammaticalized as a modal adverb: (it) may be > maybe, (it) may hap/happen > mayhap(pen). The longer form mayhappen, first attested c1577, was sometimes abbreviated in quick speech to mappen. The OED says that both adverbs mayhap and mayhappen are still alive in some dialects in Britain but are otherwise archaic:

(31) Jones Northumbrian 271: Mayhaps this lord o'ours may come to the end o'his tether some o'thae days.

(32) July 1898 Longman's Mag. 257, East Sussex: Mappen he is alive, poor chap.

Other Middle English modal adverbial formations with the root hap-were the words haply/hapliche and happily/happiliche. They were synonyms of perhaps until the 17th century, but according to Swan (1991: 417) in the late 16th century happily developed its present sense of 'by happy chance, happily, fortunately', which gradually superseded the original use of the word:

(33) c1390 PPl.A(1) (Vrn) 6.104: be dore I-closet..to holden pe per-oute Hapliche [vrr. appely, happely, happily] an Hundred zer er pou eft entre. 'The door closed to keep you outside, perhaps a hundred years before you come in again'.

(34) (a1398) *Trev.Barth.(Add 27944) 170b/a: bey ben selde ouer sette but happeliche [Lforsan] by peues oper by hunters. 'They are seldom assailed except perhaps by thieves or by hunters'.

(35) ?c1425*Chauliac(2) (Paris angl.25) rr20a/a: It holdep happely [*Ch.(1): perauenture; L forte] a glasseful. 'Perhaps it will hold a glassful'.

(36) (1462) Paston Letters 4.36: The Kyng shulde..se suyche riottes as have be in this cuntre punyshed in suche fourme as happely summe shulde hange by the nekke. 'The king should see such riots as those that occurred in this country as perhaps some should be hanged by the neck'.

(37) Shakespeare Hamlet III.i.272: Haply the Seas and Countries different With variable Obiects, shall expel This something setled matter in his heart. (see also example 4)

(38) Shakespeare 2 Henry VI III.i.306: Thy fortune, Yorke, hadst thou beene Regent there, Might happily haue prou'd farre worse then his. 


\section{Conclusion}

The comparison of the equivalents of Latin forsitan in successive translations of an example from St. Luke's Gospel shows us how English tried to express (low) probability at different stages of its development:

(39) Luke 20.13: Mittam filium meum dilectum: forsitan, cum hunc viderint, verebuntur.

Old English:

a. c990 WSCp: Ic asende minne leofan sunu wenunga hine hig forwandiað ponne hig hine geseop.

b. $\quad$ c960 LkGl (Li): ic sendo suno min leofne woen is $\boldsymbol{t}$ uutedlice miððy ðone ilca gesegon gesceomadon.

c. c960 LkGl (Ru): ic sendo suno minne leofne woen is $\boldsymbol{t}$ wutudlice miððy ðone ilco gegisegun giscomadun.

Middle English

d. 1382 Wycliffe - Early Version: I fchal fende my dereworpe fone; perauenture whanne pei fchulen fe him, pei fchulen be afchamyd.

e. 1395 Wycliffe - Late Version: Y schal sende my dereworthe sone; perauenture, whanne thei seen hym, thei schulen drede.

Early Modern English

f. 1535 Coverdale Bible: I wil sende my deare sonne, peraduenture they wil stonde in awe of him.

g. 1537 Matthew Bible: I wil sende my deare sonne, hym peraduenture they wyll reuerence, when they se hym.

h. 1568 Bishops' Bible: I wyl send my deare sonne, it may be they wyll reuerence hym, when they see hym.

i. 1582 Douay-Rheims Bible: I vvil fend my beloued fonne: perhaps vvhen they fhall fee him, they vvil reuerence him.

j. 1599 Geneva Bible: I will send my beloved son: it may be that they will do reverence when they see him.

k. 1611 King James Bible: I will send my beloued sonne: it may be they will reuerence him when they see him.

Present-day English

1. New Revised Standard Version \& New International Version: I will send my son, whom I love; perhaps they will respect him.

m. New American Bible: I shall send my beloved son; maybe they will respect him.

Old and Early Middle English did not yet have many modal sentential adverbs of low probability, which tended to be expressed with modal verbs. From the 13th 
century onwards first epistemic prepositional phrases of Anglo-Norman origin were borrowed into English consisting of the preposition per/par and nouns such as adventure, case, chance. The prepositional phrases were usually spelt separately but some univerbated examples are attested early, as well. All these new words developed two major senses: 'by chance' and 'maybe, possibly'. In the late 15th century an analogous hybrid form per-hap(s) is coined according to the same pattern and is gradually grammaticalized as a univerbated modal sentence adverb in Early Modern English. The etymology of the hybrid Romance-Germanic word $\operatorname{perhap}(s)$ is clear: it is a formation consisting of the Old French preposition per 'by, through' and the Norse noun hap 'chance'. Alongside the new formation may$b e$, a calque of French peut-être, and may-hap, perhaps superseded the competing forms, including its simpler variant perhap, in Early Modern English after two centuries of lexical layering.

According to the OED citations mayhap, perhap, percase, peradventure, and perchance became obsolete or at least obsolescent by 1700 though they still have some limited occurrence in Present-day English when used in a jocular way and/or in archaicized texts. Especially perchance is still a popular form (the entry is found, for instance, in a pedagogical Collins Cobuild Dictionary meant for learners of English), perhaps because it is used in a famous quotation from Hamlet's soliloquy:

(40) Shakespeare Hamlet III.i.60: To dye to sleepe, To sleepe, perchaunce to Dreame, I, there's the rub.

In Present-day English only perhaps and maybe are in current usage albeit with some syntactic and semantic restrictions. These "content disjuncts expressing doubt" (Hoye 1997: 184) rarely occur in interrogative clauses (Doherty 1987) and prefer sentence initial position (Swan 1988a, 1988b; Mortensen 2006: 92; Suzuki 2018b: 48). Modern dictionaries usually describe the former as a little more formal than the latter (confirmed, for example, by Suzuki's 2018bstudy) and also more commonly found in British English: according to Suzuki \& Fujiwara (2017: 827) perhaps is the most frequent "possible' modal adverb" in the British National Corpus. Although borrowed in the 14th century, the adverbs possibly and probably were not yet used in epistemic senses in Middle English. The $O E D$ (s.v.) dates their first modal uses of "contingency or subjective possibility" for 1600 and 1613, respectively. The modal likely is first found in Wycliffe and the earliest uses of the now archaic and/or dialectal belike (grammaticalized from by like) are attested in the mid-16th century.

The history of perhaps is a clear example of grammaticalization, whereby a prepositional phrase became a modal adverb, now also used as a discourse marker. We find here all the typical features of the process: phonetic attrition, 
decategorization, univerbation, and obligatorification (eliminating competing forms). The development is similar to the story of the hybrid causal conjunction because (cf. Molencki 2011, 2012).

\section{REFERENCES}

Allan, Kathryn. 2016. Borrowing and polysemy in Early Modern English. (Paper presented at the IAUPE conference in London in July 2016).

$A N D=$ Anglo-Norman dictionary. http://www.anglo-norman.net/gate/

Beijering, Karin. 2012. Expression of epistemic modality in Mainland Scandinavian. A study into the lexicalization-grammaticalization-pragmaticalization interface. Ph.D. dissertation, University of Groningen.

Brems, Lieselotte. 2012. Layering of size and type noun constructions in English. De Gruyter Mouton. DOI: 10.1515/9783110252927

Brinton, Laurel J. 2017. The evolution of pragmatic markers in English. Pathways of change. Cambridge University Press. DOI: 10.1017/9781316416013

$B \& T=$ Bosworth, Joseph $\&$ T. Northcote Toller 1898. An Anglo-Saxon dictionary. 1921. Supplement by T. Northcote Toller. 1972. Enlarged addenda and corrigenda by Alistair Campbell. Clarendon. http://lexicon.ff.cuni.cz/txt/oe_bosworthtoller.txt

Busse, Beatrix. 2010. Adverbial expressions of stance in early modern 'spoken' English. In Jörg Helbig \& René Schallegger (eds.), Anglistentag 2009 Klagenfurt: Proceedings, Wissenschaftlicher Verlag Trier. 47-64.

Busse, Beatrix. 2012. Historical text analysis: Underlying parameters and methodological procedures. In Andrea Ender, Adrian Leemann \& Bernhard Wälchli (eds.), Methods in contemporary linguistics, De Gruyter Mouton. 285-308.

DOI: $10.1515 / 9783110275681.285$

CMEPV = Corpus of Middle English Prose and Verse. https://quod.lib.umich.edu/c/cme/

Collins Cobuild Dictionary. 1995. Harper Collins Publishers.

DOE = The Dictionary of Old English. https://www.doe.utoronto.ca/pages/index.html

Doherty, Monika. 1987. Perhaps. Folia Linguistica 21(1): 45-66. DOI: 10.1515/flin.1987.21.1.45

$D S L=$ Dictionary of the Scots language, consisting of the original Dictionary of the Older Scottish Tongue and The Scottish National Dictionary. https://dsl.ac.uk/

Fernández Cuesta, Julia \& Sara M. Ponz-Sanz (eds.). 2016. The Old English gloss to the Lindisfarne Gospels: Language, author and context. De Gruyter. DOI: 10.1515/9783110449105

Fischer, Olga. 2015. An inquiry into unidirectionality as a foundational element of grammaticalization: On the role played by analogy and the synchronic grammar system in processes of language change. In Hendrik De Smet, Lobke Ghesquière \& Freek Van de Velde (eds.), On multiple source constructions in language change, John Benjamins. 43-61. DOI: 10.1075/bct.79.03fis

González Álvarez, Dolores. 1996. Epistemic disjuncts in Early Modern English. International Journal of Corpus Linguistics 1(2): 219-256. DOI: 10.1075/ijcl.1.2.04gon

Goossens, Louis. 1982. Say: Focus on the message. In René Dirven, Louis Goossens, Yvan Putseys \& Emma Vorlat (eds.), The scene of linguistic action and its perspectivization by SPEAK, TALK, SAY and TELL, John Benjamins. 85-132. DOI: 10.1075/pb.iii.6.04goo 
Haspelmath, Martin. 2004. On directionality in language change with particular reference to grammaticalization. In Olga Fischer, Muriel Norde \& Harry Perridon (eds.), Up and down the cline - The nature of grammaticalization, John Benjamins. 17-44. DOI: $10.1075 /$ tsl.59.03has

Heine, Bernd. 2013. On discourse markers: Grammaticalization, pragmaticalization, or something else? Linguistics 51(6): 1205-1247. DOI: 10.1515/ling-2013-0048

Hopper, Paul J. 1991. On some principles of grammaticalization. In Elizabeth Closs Traugott \& Bernd Heine (eds.), Approaches to grammaticalization: Vol. I: Theoretical and methodological issues, John Benjamins. 17-35. DOI: 10.1075/tsl.19.1.04hop

Hoye, Leo. 1997. Adverbs and modality in English. Longmans.

Lehmann, Christian. 1995. Thoughts on grammaticalization. Lincom Europa.

Martín Arista, Javier. 2011. Adjective formation and lexical layers in Old English. English Studies 92(3): 323-344. DOI: 10.1080/0013838X.2011.564776

Martín Arista, Javier. 2014. Noun layers in Old English: Mismatches and asymmetry in lexical derivation. Nordic Journal of English Studies 13(3): 160-178.

MEC = Middle English Compendium. http://ets.umdl.umich.edu $/ \mathrm{m} / \mathrm{mec}$

$M E D=$ Hans Kurath \& Sherman M. Kuhn (eds.). 1956-2002. Middle English dictionary. University of Michigan Press.

Molencki, Rafał. 1997. Albeit a conjunction, yet it is a clause: A counterexample to the unidirectionality hypothesis? Studia Anglica Posnaniensia 31. 163-178.

Molencki, Rafał. 2011. New prepositions and subordinating conjunctions of Romance origin in Middle English. In Jacek Fisiak \& Magdalena Bator (eds.), Foreign influences on medieval English, Peter Lang. 9-24. DOI: 10.3726/978-3-653-00857-9

Molencki, Rafał. 2012. Causal conjunctions in Mediaeval English: a corpus-based study of grammaticalization. Uniwersytet Śląski \& Oficyna Wydawnicza WW.

Molencki, Rafał. In press. From eadig to happy: The lexical replacement in the field of medieval English adjectives of fortune. In Ben Molineaux, Alpo Honkapohja \& Bettelou Los (eds.), Contact in English Historical Linguistics, John Benjamins.

Molencki, Rafał. Forthc. The rise of the verb happen in Middle English. In Letizia Vezzosi (ed.), Current explorations in Middle English, Peter Lang.

Mortensen, Janus. 2006. Epistemic and evidential sentence adverbials in Danish and English. Ph.D. dissertation, Roskilde University.

Nykiel, Jerzy. 2010. The interplay of modal verbs and adverbs: A history of maeg eape. In Ursula Lenker, Judith Huber \& Robert Mailhammer (eds.), English historical linguistics 2008:. Vol. I: The history of English verbal and nominal constructions, John Benjamins. 143-164. DOI: https://doi.org/10.1075/cilt.314.12nyk

OED = Oxford English Dictionary Online. $\mathrm{http}: / /$ www.oed.com

Onions, Charles Talbot. 1966. The Oxford dictionary of English etymology. Oxford University Press.

Palander-Collin, Minna. 1999. Grammaticalization and social embedding. I THINK and METHINKS in Middle and Early Modern English. Société Néophilologique.

Ramat, Paolo \& Davide Ricca. 1998. Sentence adverbs in the languages of Europe. In Johan van der Auwera (ed.), Adverbial constructions in the languages of Europe, De Gruyter Mouton. 187-275. DOI: 10.1515/9783110802610.187

Suzuki, Daisuke. 2018a. The semantics and pragmatics of modal adverbs: grammaticalization and (inter)subjectification of perhaps. Lingua 205. 40-53.

DOI: 10.1016/j.lingua.2017.12.014 
Suzuki, Daisuke. 2018b. Variation between modal adverbs in British English. The cases of maybe and perhaps. Functions of Language 25(3): 392-412. DOI: 10.1075/fol.16009.suz

Suzuki, Daisuke \& Takashi Fujiwara. 2017. The multifunctionality of 'possible' modal adverbs: A comparative look. Language 93(4): 827-841. DOI: 10.1353/lan.0.0176

Swan, Toril. 1988a. The development of sentence adverbs in English. Studia Linguistica 42(1): 1-17. DOI: $10.1111 / \mathrm{j} .1467-9582.1988 . t b 00782 . x$

Swan, Toril. 1988b. Sentence adverbials in English: a synchronic and diachronic investigation. Novus.

Swan, Toril. 1991. Adverbial shifts: Evidence from Norwegian and English. In Dieter Kastovsky (ed.), Historical English syntax, De Gruyter Mouton. 409-439. DOI: $10.1515 / 9783110863314.409$

Swan, Toril. 1996. Adverbialization and subject-modification in Old English. In Jacek Fisiak \& Marcin Krygier (eds.), Advances in English historical linguistics, Mouton de Gruyter. 443-456. DOI: 10.1515/9783110804072.443

Traugott, Elizabeth Closs. 1989. On the rise of epistemic meanings in English: An example of subjectification in semantic change. Language 65(1): 31-55. DOI: $10.2307 / 414841$

Traugott, Elizabeth Closs. 1995. The role of discourse markers in a theory of grammaticalization. (Paper presented at ICHL XII, Manchester 1995, available at https://web.stanford.edu/ $\sim$ traugott/papers/discourse.pdf)

Traugott, Elizabeth Closs. 2006. Historical aspects of modality. In William Frawley (ed.), The expression of modality, De Gruyter Mouton. 107-139. DOI: 10.1515/9783110197570.107

Vanhowe, Martine (ed.). 2008. From polysemy to semantic change: Towards a typology of lexical semantic associations. John Benjamins. DOI: 10.1075/slcs.106

Wells, Stanley, Gary Taylor, John Jowett \& William Montgomery (eds.). 1987. The Oxford Shakespeare: The complete works: Original-spelling edition. Oxford University Press. 